\title{
Hamsa
}

Journal of Judaic and Islamic Studies

\author{
$7 \mid 2021$ \\ Visibility of Religious Difference in Medieval Europe \\ and the Mediterranean
}

\section{Artur de Barros Basto | Abraham Israel Ben-Rosh: a "Special Man" Seen by Foreigners}

Hervé Baudry

\section{(2) OpenEdition}

Journals

Electronic version

URL: https://journals.openedition.org/hamsa/1524

DOI: $10.4000 /$ hamsa. 1524

ISSN: 2183-2633

\section{Publisher}

CIDEHUS - Centro Interdisciplinar de História Culturas e Sociedades da Universidade de Évora

Electronic reference

Hervé Baudry, "Artur de Barros Basto | Abraham Israel Ben-Rosh: a "Special Man" Seen by Foreigners", Hamsa [Online], 7 | 2021, Online since 07 September 2021, connection on 27 September 2021. URL: http://journals.openedition.org/hamsa/1524 ; DOI: https://doi.org/10.4000/hamsa.1524

This text was automatically generated on 27 September 2021.

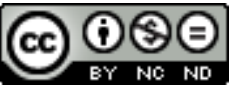

Hamsa est mise à disposition selon les termes de la Licence Creative Commons Attribution - Pas d'Utilisation Commerciale - Pas de Modification 4.0 International. 


\title{
Artur de Barros Basto | Abraham Israel Ben-Rosh: a "Special Man"1 Seen by Foreigners
}

\author{
Hervé Baudry
}

\section{Barros Basto is a legend ${ }^{2}$}

1 Numerous written works have been inspired by the life and work of Arthur Carlos de Barros Basto | Abraham Israel Ben-Rosh, a major figure in the history of the so-called rediscovery of the Portuguese Marranos and of the renaissance of Judaism in Portugal ${ }^{3}$. Barros Basto became a renowned figure, particularly between 1926, when he launched his Obra do Resgate (Work of Redemption or Rescue Work), and 1938, the year the synagogue of Oporto was inaugurated. In 1925, the situation of Jewish descendants in Portugal country received considerable attention thanks to Samuel Schwarz's book Os Cristãos-Novos em Portugal no Século $\mathrm{XX}^{4}$, which was published in several languages, and in various summarized versions. A survey produced by Lucien Wolf for the Anglo-Jewish Association and the Alliance israélite universelle put Barros Basto in the spotlight in terms of the revival of Judaism in Portugal ${ }^{5}$. In 1926 Lucien Dreyfus initiated a review of the translation of Uriel da Costa's autobiography, stating that "The Marranos are fashionable"6. In fact, they were so fashionable that in 1930 an anonymous Russian author sardonically wrote at the end of an article on Soviet anti-semitism "Captain Barros Basto, we'll soon have Marranos in Russia"7. Barros Basto gained international recognition in the 1930s, though he would later be better known as the "Portuguese Dreyfus". The pre-war figure of Captain Barros Basto tends to be sidelined, or even ignored, despite the international rediscovery of the Portuguese Marranos in the 1990's perhaps understandably; Jacques Brenner and Stan Neumann's famous documentary les Derniers Marranes was filmed in Belmonte ${ }^{9}$, a place that was included in Barros Basto sphere of action. None of the foreign historical documentaries, such as A História dos 
Judeus em Portugal ${ }^{10}$, History's Ultimate Nomads - Portugal ${ }^{11}$ and The Portuguese Jewish Legacy ${ }^{12}$ make any reference to him.

The present study intends to challenge the obscurity surrounding this important and fascinating character by examining some of the many people who came to visit him from Europe, America and Asia. We will address the questions of who they were and what they were drawn to, and how Barros Basto was portrayed in their written testimonies. The authors of his biography, published in $1997^{13}$, focus particularly on the organization of the Jewish community of Oporto and the multiple religious and pedagogical issues Barros Basto and some of his visitors faced. It contributes to a polyphonic depiction through the testimonies delivered in the period of the Marrano Revival.

\section{Barros Basto's visitors}

3 From 1926 onwards the European press, mainly Jewish writers, gave more and more visibility to what was seen as a lost tribe of Israel ${ }^{14}$. Captain Barros Basto became a center of attention, particularly in Europe (England, France, Germany), due, of course, to Portugal's geographical proximity: the journey by train from Paris to Oporto took less than two days, plus a half day for the expedition led by Barros Basto from Oporto to the Marranos in the north of Portugal. However, the geographical closeness did not diminish the travelers' enchantment, and in October 1929, Jean-Javal crossed the French border "burning with the fever of explorers who go out to discover a new continent" ${ }^{15}$.

4 At least forty-four personalities - intellectuals, scholars, rabbis, activists, journalists, or simply admirers, most of them men, came to Oporto to visit Barros Basto between 1927 and $1938^{16}$. Some visits are qualified by Ha-Lapid as "important" and "illustrious", "and there were even two pastoral visits by rabbis. The first of them was Lucien Wolf who visited the communities of Lisbon and Oporto in order to verify the existence of the Marranos and to propose measures on behalf of the Alliance Israélite Universelle (Paris) and the Anglo-Jewish Association (London). Others played a critical part in Barros Basto's activity and rise to fame, like Cecil Roth, Paul Goodman, Nahum Slouschz or Marcus Ehrenpreis, a rabbi from Stockholm.

5 Some of the visitors played a crucial role in the community life. The most frequent visitor, Marcel Goldschmidt, a silk manufacturer and president of the Consistory of Lyon, was elected a protector member of the Oporto Jewish community in $1931^{17}$. And two years later, Elias Kadoorie, from a wealthy British family from Shanghai, was elected member emeritus in recognition of his contributions to the Jewish community ${ }^{18}$. He was the main financial patron of the new synagogue of Oporto. "Captain Barros Basto's great work" ${ }^{19}$ was consecrated as the "Sinagoga Kadoorie Mekor Haim"

6 All these visitors met personally with Barros Basto and often had brief contact with some of his friends, like doctor Almeida, who would substitute the captain when he was engaged in his military duties. They must have visited the original Mekor Haïm synagogue at least once; it was established in 1927 and consisted of a "simple room" ${ }^{21}$ in the centre of the city, Rua Poço das Patas. After 1929 they could observe the construction work of the great synagogue, the first stone of which was laid on June 30, $1929^{22}$. Like Samuel Schwarz, Barros Basto published the results of his historical 
research ${ }^{23}$, and would take his visitors to discover the city's points of interest, especially the ruins of the old Jewry.

\section{Barros Basto seen by his visitors}

Some of the foreign visitors who came to see Barros Basto were writers, and their interest in the crypto-Jews and the Obra do Resgate was as strong as their curiosity to meet its author; at least eleven of them published related books, essays or articles, mostly in English, French and German ${ }^{24}$. Some works were often published in Ha-Lapid, including articles by Paul Goodman, the Secretary to the Spanish and Portuguese Jews' Congregation, Cecil Roth, a Professor of History at Oxford, and, on a more personal and aesthetic level, a French writer, Lily Jean-Javal. Two of the latter's poems in French were inspired by her journey to Oporto and North-Eastern Portugal and were published in full on the front page of Ha-Lapid ("A Bragance, dans le sombre Tras-os-Montes...", "Porto" 25 ).

If we put ourselves in the place of Barros Basto's visitors, we can imagine that they met an individual with a triple life: civil, religious and military. No testimony is given about his family, and his wife and two children rarely appear ${ }^{26}$. According to accounts, the first meetings took place in public places, at São Bento train station (Roth) or at the hotel (Jean-Javal). Most of the texts in which he figures are travel narratives or other kinds of reports. The most personal account of all was written by Jean-Javal: having heard about the captain in Paul-Louis Couchoud's book published in 1928, L'Étudiant des religions, she decided to go to Portugal with Alice Monod, a Protestant friend of her. Besides narrating her travel experience, she described Barros Basto's life, especially his youth, at a conference at the Shema Israël in Paris, which was later published by the association and in $\mathrm{Ha}-\mathrm{Lapid}^{27}$.

The portrayal that can be drawn from these testimonies will be divided into three sections according to the appearances and activities that Barros Basto shared with his companions: 1 . the soldier; 2 . the pastor; 3 . the "enthusiast".

\subsection{The soldier}

Barros Basto entered the army in 1909 as a pupil at the School of Infantry and Cavalry. During the First World War he was a lieutenant in Northern France, in 1917-1918 Upon his return to Portugal he was decorated for his acts of bravery and honor and promoted to the rank of captain. His reputation was illustrated by Paul Goodman who referred to him as "the courageous officer" 28 and "the gallant captain" 29 . A day before Lily JeanJaval was to meet Barros Basto, she wrote in her diary: "I have seen his picture: a military officer wearing a moustache". The following day, she gave an account of the meeting at noon at the hotel: "he is waiting for me, standing in his blue infantry uniform [...], he has shaved his moustache" ${ }^{30}$. According to Samuel Schwarz visitors usually met the "ex-marano captain" in uniform ${ }^{31}$. Barros Basto, the "Portuguese Dreyfus", soon became aware of the difficulties he would encounter in the army by making public his conversion to Judaism. Robert Lœwel, a famous French lawyer and writer, describes him "an elegant officer, strapped into a gray uniform, carrying over the chest multicolored proof of his valiant attitude in Flanders during the war" ${ }^{32}$. During the interview that took place in the bar of the same hotel where Jean-Javal was 
hosted, the officier confessed to him: "I have sometimes been personally advised to leave "my jewry"'33. After he was expelled from the army in 193734, Barros Basto was prohibited from wearing both the uniform and his decorations in public while the international situation made the visitors rarer, in particular from the Nazi accession to power in 1933 (see below, Table 1).

Table 1 - Number of visitors per year

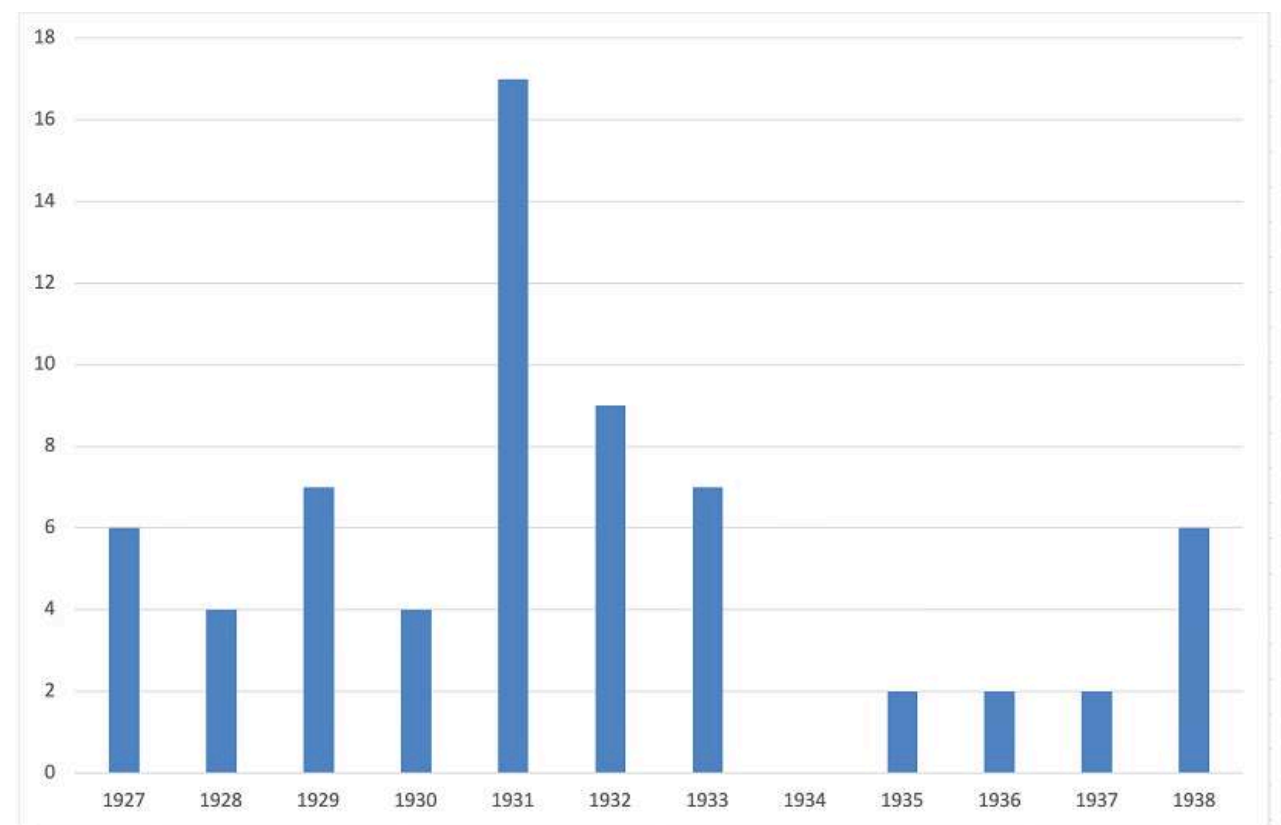

\subsection{The pastor}

11 As Lucien Wolf stated in 1926, three years after the creation of the Jewish Community of Oporto (August 1,19235), Barros Basto was "the only Marrano who, in the last hundred and fifty years, [had] entered a Synagogue" ${ }^{36}$. Obviously, after converting to Judaism, he renounced all military and political ambitions ${ }^{37}$. But his pioneering proselytism could not but catch the attention. The visitors who met Barros Basto were fascinated by "the apostle of the Marranos"38. Cecil Roth's text was translated into five languages ${ }^{39}$, and had great impact on the outcome of Barros Basto's activities; visitors wanted to see "the inspiring guide of this movement" 40 , the "leader of those who want to return to Judaism" 41 and live "north of the Tagus" ${ }^{42}$. Against the intentions of Mordechai Van Son, an engineer from Hilversum, who, after a passage in the Lisbon Jewish community, went to Oporto and advocated for the relocation of the school and theological institute to the capital, the Portuguese Marano Committee, established in London, reiterated its confidence in Barros Basto saying that he had fully proved to be "a leader of faith and vision" ${ }_{43}$.

Cecil Roth attended Shabbat presided over by Barros Basto, half in Hebrew half in Portuguese, mixing Ashkenazim and Marranos who were uneasy with official Judaism. He was aware of the difficulty of organizing and acting in a small community with no rabbi and no yeshiva. He explained: "This is pioneering work, nothing of the kind has ever been done and no past experience can serve as reference [...] He is the man we can trust and if he happens to get it wrong, it is because he is too enthusiastic" ${ }^{44}$. Speaking 
to Jean-Javal, Barros Basto defined himself as "the prophet of will" 45 , and she was persuaded that he was perfectly capable of tackling any complexity: "Various communities are here, from Poland, Galicia, Russia, France, America and so on; there are four or five Marranos [...]. Everyone would like to impose their own particular rites. But the driving force ["animateur"] of this minority, the one who awakens the sleeping soul of Israel in Portugal, Captain Barros Basto, brought books from Livorno and everyone bowed" ${ }^{46}$. Another day, she was deeply impressed by his singing HaTikvah with the congregation ${ }^{47}$.

13 A certain trend toward mythicization can be observed in the writings on Barros Basto. Ehrenpreis, first published in Swedish in 1927, wrote in a more lyrical tone: "Like a legendary prophet, he walks - I would say: he glides - lonely on the road of his vocation [...]. Like Joseph he went away in search of his brethren"48. Paul Goodman wrote in 1938 he "recalls the romantic Sefardi of the Judaic faith" 49 . The strong impression left by the Messenger of Redemption, who was not a rabbi nor an "official religious guide" ${ }^{50}$, is reflected by biblical references to him from his learned visitors, i.e. comparing him to Abraham. Significantly, when the pastor met his flock in the remote Northeastern regions of Portugal, people envisaged more simple images. For example, HaLapid recalled a brief meeting on the road to Bragança: on a stormy day, several old women came up to Barros Basto saying that "they did not want to die without having heard the man from Oporto who spoke of our Law"51.

\subsection{The enthusiast}

Lucien Wolf summed up Barros Basto's responsibilities toward the Community by claiming that he was its "good fairy" 52 . A mixture of paternal/maternal figure, religious and military authority, the leader is portrayed by people who accompanied him in his daily life and could describe his personality through aspects that made him more familiar. Barros Basto was a man of many skills: for Ehrenpreis, he was a "professor, organizer, translator, researcher, secular priest, preacher, journalist" ${ }^{53}$. He was also a historian and tourist guide ${ }^{54}$. Moreover, Ehrenpreis saw in Barros Basto's life "a novel of religious psychology", reflecting the exceptional dimension of his story ${ }^{55}$. It was universally recognized that due to his past, his return to Judaism and his knowledge of the Marranos, he was the right man in the right place. Psychology here implies special human capacities to achieve a particularly difficult mission.

Apart from possessing the psychological and intellectual skills necessary for an unofficial spiritual leader, Barros Basto had a simple human dimension, and both Roth and Jean-Javal were seduced at first sight. On the one hand, there was an amazing encounter between the Englishman who saw in Barros Basto, despite his excellent French, "the perfect kind of British naval officer", and the Portuguese who expected to meet a "grey bearded and wise man" ${ }^{56}$. On the other hand, there was the meeting between the French female writer and the captain, and according to whom, both felt immediate empathy for each other. Visiting the Marranos in the northern region of Portugal was described by Cecil Roth as "maybe the most fabulous adventure in modern history" ${ }^{\prime 2}$.

It is thus tempting to rename Jean-Javal's book Sous le charme de Barros Basto (Under the charm of Barros Basto). "Charming" means charismatic, that is, in Roth's terms, to possess a "magnetic personality" ${ }^{8}$. Barros Basto left a lasting impression on his 
visitors: his smile, as a sign of confidence ${ }^{59}$, was also something she might have associated with his youthful character of merry storyteller and reciter of poems. Likewise, Ismar Elbogen, o reitor do seminário rabínico de Berlim, referred to his "youthful heart"60. A good hazan at the synagogue who liked to sing in daily life: during the trip to Bragança with Jean-Javal and her friend "he was humming fados, that of the shepherdess and the shepherd who kissed each other, that of the devil" ${ }^{61}$. Another aspect of his personality was his sense of humor and his ability to laugh at himself. "What impressed me most is his humor. This rarely happens with a propagandist." [...] Asked about the creation of a Jewish cemetery at Oporto, he explained that things were advancing very slowly: "So, what do you do in the meantime? - By order of the mahamad [council of elders], the members of the Oporto community are forbidden to die before measures are taken for their burial" ${ }^{6}$. Between brackets Roth reported that Barros Basto was the "Messenger of Redemption (as he fancifully calls himself )" 63 . Obviously, this was in no way underestimating his mission but reflected his tendency to self-derision that could be considered his Jewish humor ${ }^{64}$. He had the same attitude in relation to his military identity, impersonating an officer gentleman and protector of ladies. Passing in front of a dark tavern in a run-down part of the city, he appeased the French woman exhibiting his uniform and gun ${ }^{65}$.

Maybe more than an "apostle", Barros Basto was a man who turned a "dream made of stones" ${ }^{66}$ into a reality. In 1938 he said, with reason, that he had "accomplished the first part of his work" ${ }^{\prime 7}$. Jean-Javal later quoted that metaphor, probably because it was Barros Basto's expression. Both from our point of view and that of his visitors, the Oporto synagogue, described by Goodman as "the Jewish cathedral of the North of Portugal" ${ }^{68}$, was actually his most important achievement. In another text, Goodman expressed his extreme admiration: "It is difficult to imagine that only one man had the idea of establishing a house of prayer in a city and in a time with no Jews; it is difficult to believe that this man, on his own, contributed single-handedly so much to this mission" ${ }^{69}$. Mekor Haïm was Barros Basto's response to "the indifference and skepticism of some of [his] co-religionaries who remain in darkness and oblivion", and the symbol of the "Resurrection of Israel in Portugal" "a miracle of modern Jewish life" "11.

A "New Jew"72, Barros Basto was born a fighter and an organizer driven by an idealistic eagerness to transform both reality and human beings. This enthusiasm and his capacity to face challenges and overcome obstacles deeply impressed his visitors. "We wish for this special man that his work may blossom and grow, and we affectionately call him 'Chasak Weemaz' [strong and courageous]"73.

Barros Basto was in continuous correspondence with Goodman during his military trial ${ }^{74}$. Elbogen was probably also aware of the tragedy that had befallen the captain. In September 1937, four months before the inauguration of the synagogue, Barros Basto was notified of his sentence. In the same article that praised the "man who promoted the renaissance of the community", Elbogen alluded to the "serious campaigns that tried to ruin his work. He weathered the attacks and prevailed"75. His conviction did not get in the way of his mission and the Oporto synagogue opened its doors right when the world was about to fall into an abyss. In 1938, Mekor Haïm was "a sign of the new freedom here"76, contrary to what had been happening in Germany since 1933. 


\section{Conclusion}

Barros Basto died in 1961. His two most important mentors, Lucien Wolf and Paul Goodman passed into the "future world" 77 in 1930 and in 1949 respectively. Ismar Elbogen emigrated to the United States in 1938. Cecil Roth, who had considered Barros Basto as "one of the most remarkable Jewish personalities of our times" 78 and dedicated several pages to him in the chapter on "the Marranos of Today" of his History of the Marranos $^{79}$, later lost the "great romanticism" that had inspired him in the thirties ${ }^{80}$. After the Second World War times changed and Barros Basto was relegated to a position of secondary importance by a series of events: his exclusion from the Army in 1937, "the rise of Nazism and the Holocaust, the creation of the State of Israel, and fear during the Salazar regime of demonstrating in public any religious faith other than Catholicism, which resulted in a thick veil of silence and intentional oblivion, as if nothing had transpired in previous years" $"$.

21 It was not until the 1990s that Barros Basto's name reappeared thanks to his wife and daughter who had been fighting since 1975 for his rehabilitation. A similar process was taking place with the Portuguese diplomat Aristides de Sousa Mendes, a Righteous after $1966^{82}$ but rehabilitated by the Portuguese Republic only in 1995. Meanwhile, reflecting upon the destiny of the Portuguese Marranos had become necessary. Significantly, in a rare article on Barros Basto's death, Yomtov Bato, who never met him, attempted to understand why the Portuguese Marranos had no longer been reported since the end of the 1930's, pointing out a "strange silence" ${ }^{83}$. For Bato, it was Salazar, the Catholic dictator, paradoxically himself a Marrano, who put an end to the revival of Judaism in his country and repressed his most prominent proselyte: "Salazar succeeded in definitely silencing the Marranos move" and Barros Basto, a "heroic fighter", was the "victim of Salazar's dictatorial regime arbitrary"

At the risk of a certain anachronism and with no regard to theological issues, the question can be put in these terms: ending centuries of a clandestine existence, Basto's work of Redemption promoted the coming-out of crypto-Jews, in particular in remote towns and villages. Legalizing communities, opening synagogues, the Portuguese Marranos' move to Judaism became a historical landmark in the newly instated Portuguese Republic and there was a spectacular acceleration in the emancipation process of the Jews of Portugal ${ }^{85}$. But its pioneer, Samuel Schwarz, became very pessimistic at the end of his life (he died in 1953). Without alluding either to his role or to that of Barros Basto, both recognized messengers of the Work of Redemption, he wrote: "Thirty, forty years ago, in some Northern provinces there were still clusters of New Christians that followed some Jewish religious traditions. These crypto-Jewish traditions are now clearly disappearing. Where the Inquisition did not succeed with three centuries of persecutions and burning at the stake this was achieved in three decades of tolerance and freedom" ${ }^{\text {". }}$. As Barros Basto's biographers wrote, "the Marranos were a thing of the past" ${ }^{17}$. More accurately, Livia Parnes referred to a return to secrecy in the $1960 \mathrm{~s}^{88}$. The status of secrecy is a basic condition of the Marranos' religious practices ${ }^{89}$. Therefore, crypto-Judaism was condemned since redemption meant the return to official Judaism. But, precisely, the rediscovery of the Marranos in the 1990's contradicts this negative balance. According to Livia Parnes, Lucien Wolf made the right choice when in 1926 he chose to support Oporto instead of Lisbon for the Work of Redemption, arguing, among other things, that the captain was a counter- 
model of the over-cautious attitude of the members of the community of Lisbon led by Moisés Amzalak ${ }^{90}$.

Did Barros Basto read Schwarz's balance that involved thirty years of his own passion? In September 1958, unexpectedly the last issue of HaLapid was published ${ }^{91}$. However, it is not our purpose here to assess all the consequences of the Work of Redemption, but it cannot be ignored. Halévy referred to "the unfortunate Barros Basto who succeeded in the 1930s in bringing at best some three dozen (!) peasant children to Judaism"92. The following table shows the numbers of brit milah between 1927 and $1938^{93}$, with a total of sixty-five from varied ages and social origins (see below Table 2).

Table 2 - Number of brit milah per year (from HaLapid, April 1927-December 1938)

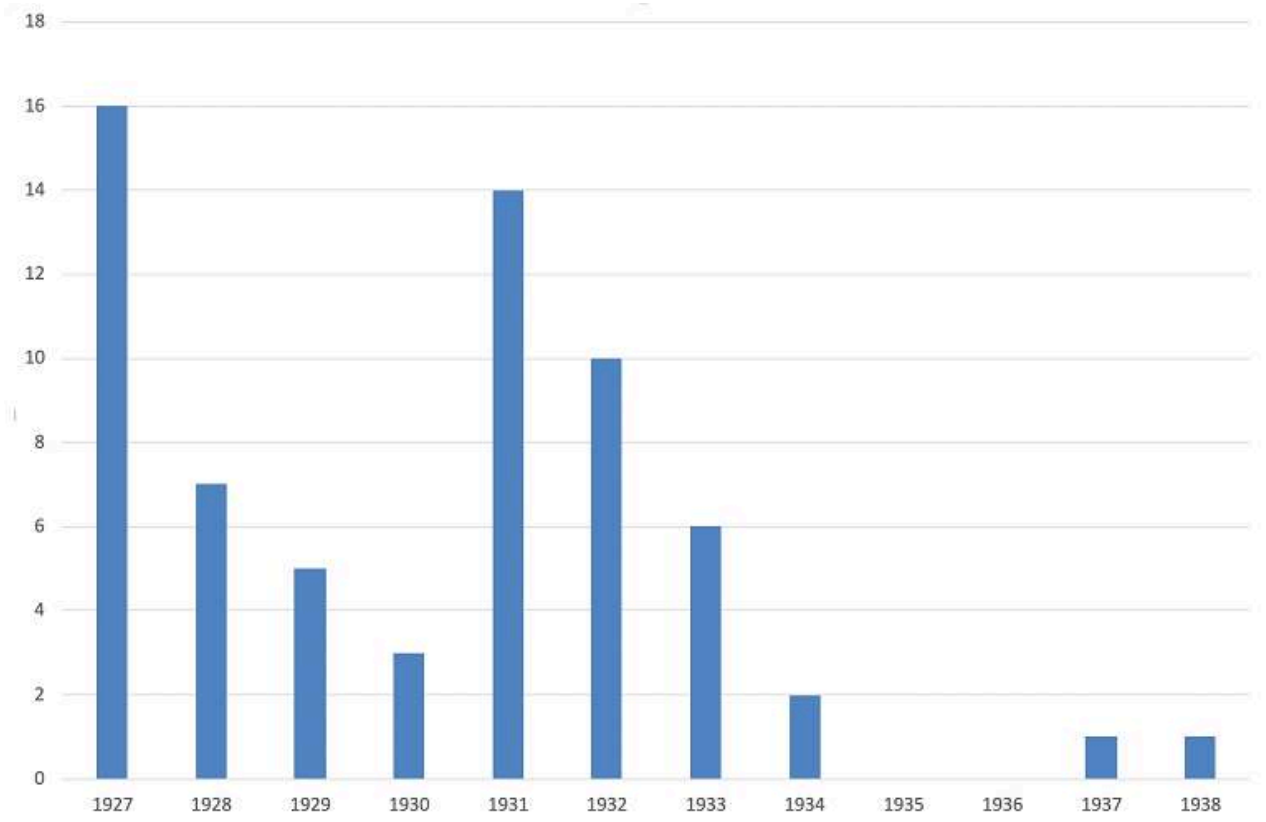

Though higher than this approximation, the number of the (re)conversions to Judaism remained low and unequally distributed along these years. A survey of the multiple activities achieved by Barros Basto and his collaborators, in Oporto and in the other communities and places in Northern Portugal, and the events reflecting the pre-war public Jewish social life (not to speak of the support to refugees before, during and after the war) would no doubt help answer more accurately the question whether the Work of Redemption was necessary or, as a whole, a mistake. Barros Basto, the Builder of a community and its house remains a unique figure through an inscription made on the stone of honor, with the Kadoorie family, by the Spanish and Portuguese Jews' Congregation of London" ${ }^{94}$ " "This Tablet is erected by the Portuguese Marranos Committee of London in honor of Captain Artur Carlos de Barros Basto as a tribute to the historic services rendered by him as the Leader of the Jewish Work of Redemption in Portugal and in the establishment of this Synagogue with which his name will be associated for all time" ${ }^{95}$.

\section{List 1: Visitors from 1927 to $1938^{96}$}

1. Lucien Wolf (London): January 1927 
2. Frank I. Hassan (London): May 1927

3. Nissim Danon (Jerusalem): July 1927

4. Marcel Goldschmidt (Lyon): July 1927; May 1929; Winter 1931; end of Summer 1931; December 1931-January? 1932; July 1932

5. Kuhnegg (?): October 1927

6. Nahum Slouschz (Paris): December 1927

7. Kiefer (Frankfurt): January 1928; Winter 1931

8. Louis Goldschmidt (Marcel's brother) (France): January 1928

9. Van Son (Hilversum): June 1928; Summer 1931

10. Jacob Nachbin (Rio de Janeiro): End of 1928

11. Cecil Roth (Oxford): May 1929

12. David de Sola Pool (New York): Summer 1929; January 1938

13. Hugo Baermann (Nüremberg): September 1929

14. Lily Jean-Javal (Paris): October 1929

15. Otto Aronade (Poland): October 1929

16. Moritz Kaufmann (Frankfurt): December 1929

17. Luiz Weil (Salamanca): Winter 1930

18. Robert Asseo (Istanbul): Spring 1930

19. Felix Aber (Bremen): Summer 1930

20. Baruch Ben-Jacob (Thessaloniki): End of 1930; 1931

21. Edwin Edwards (London): Winter 1931; December 1931-January 1932; July 1932; June 1933; November 1935; April 1937; January 1938

22. Pessar Dobrouch Keso (Paris): Spring 1931

23. B. Gast (Hilversum): Spring 1931

24. Samuel Cohn (Hamburg): Spring 1931

25. S. Eschborn (Berlin): May-June 1931

26. Max Einstein (Berlin): May-June 1931

27. Leopold Wertheimer (Frankfurt): May-June 1931

28. Otto Diesenberg (Köln): May-June 1931

29. Paul Goodman (London): June 1931; January 1935; January 1938

30. Benjamin Mintz (Tel Aviv): December 1931-January 1932

31. Ettinghausen (London): July 1932

32. Da Costa Magalhães (Rio de Janeiro): July 1932

33. Semtob Gaguine (England): July 1932

34. Irade Jaime Roffé (Pará, Brasil): June 1933

35. Robert Lœwel (Paris): Summer 1932 ${ }^{97}$

36. [Pascale] Saisset (France): Early Summer 1933

37. Paul Querett (France): Summer 1933

38. Mrs. Roland (France): Early Summer 1933

39. Alfred Klee (Berlin): Summer 1933; January 1938

40. Elias Kadoorie (Shangai): September 1933

41. Ismar Elbogen (Berlin): September 1936; January 1938

42. Fritz Weil (Germany): September 1936 


\section{List 2: Texts on Barros Basto (1926-1938)}

- Lucien Wolf, Les marranes ou crypto-juifs du Portugal (Paris, 1926)

• האנוסים בפורטוגאל,Nahum Slouschz (Ha-Anussim be-Portugal) (Tel Aviv, 1927, 1930;1932)

- Marcus Ehrenpreis, Landet mellan Öster och Väster (Stockholm, 1927; German translation 1928, French translation 1930)

- Paul Goodman, Os Marranos Portugueses (French text \& Portuguese translation in Ha-Lapid nr. 8), Paris, 1928; Chez les Marranes du Portugal (Strasbourg, 1932); Les Marranes du Portugal (Paris, 1938)

- Paul-Louis Couchoud, L'Étudiant des religions (Paris, 1928)

- Otto Aronade, Reiseeindrücke in Spanien und Portugal (Berlin, 1929)

- Cecil Roth, L'Apôtre des Maranes (Paris, 1930); A History of the Marranos (Philadelphia, 1932, 1934, 1959, 1971)

- Felix Aber, In der Stadt der Maranen (Bremen, 1930?)

- Benjamin Mintz, Von den portugiesischen Marannen. Todos judeus. Unter den portugiesischen Marannen (1930-1932)

- Lily Jean-Javal, Sous le charme du Portugal (Paris, 1931)

- Mordechai Van Son, Verleden en heden der Marranen in Portugal (Amsterdam, 1930)

- Mordechai Van Son, The Marranos part the curtains (New York, 1933)

- Robert Lœwel, Les Maranes du Portugal (Paris, 1933)

- Robert Lœwel, Porto in A la recherche de Torquemada, voyage dans les ombres sanglantes de la Péninsule (Paris, 1938)

- Ismar Elbogen, "Synagogenweihe in Oporto. Zum fünfzigsten Geburtstag des Hauptmanns Barros Basto" (Central Verein Zeitung, 1938)

\section{BIBLIOGRAPHY}

A Sinagoga do Porto: da judiaria velha a Barros Basto = The Oporto Synagogue: from the Old Jewish Quarter to Barros Basto, Porto, Comunidade Israelita do Porto, Fronteira do Caos, 2014.

Anonimus, “Capitaine Barros Basto, nous aurons bientôt des Marranes en Russie", L'Univers israélite (31.1.1930), p. 553 (UI).

“Aristides de Sousa Mendes”, https://www.yadvashem.org/righteous/stories/mendes.html (accessed 20.10.2019).

“Au 'Chema' Mme Lily Jean-Javal et les Maranes”, UI, 7.3.1930, p. 717.

Barros Basto, o Capitão mal-amado, RTP, 2003 (50').

Barros Basto: o Capitão nas trincheiras, Centro Português de Fotografia, Abrantes, Câmara Municipal de Amarante/Biblioteca Municipal Albano Sardoeira, 2015. 
BASTO, Artur C. de Barros, Os Judeus no velho Porto, Lisbon, [s.n.], 1929.

BATO, Yomtov, "Was geschah mit Barros Basto? Um das Schicksal der Marranen in Portugal”, Israelitisches Wochenblatt (6.10.1961), p. 17.

BAUDRY-KRUGER, H. (ed.), La Renaissance du judaïsme au Portugal au XXe siècle. Artur de Barros Basto | Abraham Israel Ben-Rosh, Chauray, La Ligne d'ombre, 2017.

BRENNER, Jacques and Stan Neumann, Les Derniers Marranes, Les films d'ici, 1990, 52.

COHEN, Dov, "Uma aproximação à atividade literária do Capitão Barros Basto”, Cadernos de Estudos Sefarditas 18 (Maio 2018), p. 61-98.

DREYFUS, Lucien, “Uriel da Costa”, Tribune Juive de Strasbourg 21 (18.5.1926), pp. 300-301.

EHRENPREIS, Marcus, Le Pays entre Orient et Occident, Paris, Rieder, 1930.

ELADAN, J., Poètes juifs de langue française, Paris, Noël Blandin, 1992.

ELBOGEN, Ismar, "Para a Inauguração da Sinagoga do Porto. Para o 50 Aniversario do Cap. Barros Basto”, Ha-Lapid, no 82 (November-December 1937), p. 8 (abbreviated in HL).

ELBOGEN, Ismar, "Synagogenweihe in Oporto. Zum fünfzigsten Geburtstag des Hauptmanns Barros Basto", Central Verein Zeitung 2 (13.1.1938), pp. 3-4.

ELGER, Elaine and Luize Valente, A História dos Judeus em Portugal, Fototema, 2003, 56.

GERBER, Jane, The Portuguese Jewish Legacy, Congregation Shearith Israel, 2013, 59.

GOODMAN, Paul, "Les Marranes portugais. Inauguration de la synagogue Kaddorie”, Le judaïsme sephardi, 58 (31.1.1938), pp. 3-5.

GOODMAN, “L'inauguration du Temple Kadoorie à Porto", in Le judaïsme sephardi, nº 58 (16.1.1938), p. 18.

GOODMAN, Paul, “Os Maranos Portugueses. Inauguração da Sinagoga Kadoorie”, in HL 83 (January-February 1938), p. 3.

Ha-Lapid (HL), nºs 1 (April 1927), 2 (May 1927), 8 (January 1928), 16 (December 1928-January 1929), 18 (March-April 1929), 19 (April-May 1929), 22 (August-September 1929), 24 (October 1929), 25 (November 1929), 26 (December 1929), p. 3-5, 29 (March-April 1930), 31 (June-July 1930), 32 (JulyAugust 1930), 35 (December 1930), 40 (June 1931), 42 (August-September 1931), 45 (December 1931-January 1932), 59 (September 1933), 62 (February 1934), 69 (December 1934-February 1935), 74 (December 1936), 77 (October-November 1936), 79 (April 1937), 82 (November-December 1937), 83 (January-February 1938), 84 (March 1938), 85 (April-May 1938), 87 (September 1938), 100 (July-August 1940), 156 (September 1958).

JEAN-JAVAL, Lily, "Le Capitaine Carlos de Barros Basto", in Bulletin de Chema Israël et des associations d'éducation et de propagande religieuses, 49 (1930).

JEAN-JAVAL, Lily, Nuages, poèmes. Gravures sur bois de L. Lucien Faure-Dujarric, Paris, Lucien Dorbon, 1933.

JEAN-JAVAL, Lily, Sous le charme du Portugal. Visages et paysages, Paris, Plon, 1931.

JEAN-JAVAL, Lily, “Une Synagogue s'élève à Porto”, in HL 35 (December 1930), p. 6.

KESLASSI, Shaul, History's Ultimate Nomads - Portugal, Ruthfilms, 2011, 30.

KLATZMANN, Joseph, L'Humour juif, Paris, Que sais-je?, 2009. 
LEWEL [= LOEWEL], Robert Lewel, “Les Marranes du Portugal”, Archives israélites, 26-27 (6.7.1933), p. 106.

LOEWEL, Robert, À la recherche de Torquemada, voyage dans les ombres sanglantes de la Péninsule, Paris, Denoël, 1938.

MALTZ, Judy, “Descendants of the 'Portuguese Dreyfus' Still Waiting for Justice”, Haaretz (20.8.2015), online: https://www.haaretz.com/jewish/.premium-descendants-of-the-portuguesedreyfus-still-waiting-for-justice-1.5388995.

MARTINS, Jorge, A República e os Judeus, Lisboa, Nova Vega, 2010.

MEA, Elvira de Azevedo and Inácio Steinhardt, Ben-Rosh. Biografia do Capitão Barros Basto o Apóstolo dos Marranos, Porto, Edições Afrontamento, 1997.

PARNES, Livia, Ha-Lapid (O Facho): Le journal des Marranes Portugais (Porto, 1927-1958): première approche, Master Dissertation, Université de Paris-Sorbonne, 1994.

PARNES, Livia, Présences juives dans le Portugal contemporain (1820-1938), PhD. Dissertation, Paris, EHESS, 2002.

PARNES, Livia, "Samuel Schwarz, chercheur infatigable. Quand le Portugal redécouvre ses marranes", in Akadem, http://www.akadem.org/sommaire/themes/histoire/diasporas/quand-leportugal-redecouvre-ses-marranes-23-02-2016-78458_4602.php, at 72'; accessed 20.10.2019.

ROSENTHAL, Elaine and Robert, “The Portuguese Dreyfus”, Midstream 2 (1987), pp. 44-48.

ROTH, Cecil, A History of the Marranos. Fourth edition with a new introduction by Herman P. Salomon, New York, Schocken Books, 4th ed., 1975.

ROTH, Cecil, “L’Apôtre des Maranes”, in UI, 10 (17, 24.1.1930), pp. 453-455, 489-491, 521-522.

ROTH, Cecil, “O Apóstolo dos Maranos (Recordações de viagem em Portugal)”, in HL 25 (November 1929), pp. 1-5 and 26 (December 1929), pp. 3-5.

SCHWARZ, Samuel, La Découverte des marranes: les crypto-juifs au Portugal, Paris, Chandeigne, 2015.

SCHWARZ, Samuel, "História da moderna Comunidade Israelita de Lisboa", in O Instituto: Jornal scientifico e litterario, 120 (1958), pp. 140-200.

SCHWARZ, Samuel, Os Cristãos Novos em Portugal no século XX, Lisboa, Tipografia do Comercio, 1925.

SOLA POOL, David de, “The Marranos”, Jewish Quarterly Review, 24-3 (Jan. 1933), pp. 247-250.

STARCK, Johann von, Über Krypto-Katholicismus, Proselytenmacherey, Jesuitismus, Frankfurt und Leipzig, Johann Georg Fleischer, 1787.

STEINHARDT, Inácio, "Captain Barros Basto, the Apostle of the Marranos", in http:// www.steinhardts.com/LIBRARY/Biographies/ captain.html

STUCZYNSKI, Claude B., "Marranismo, mito y realidad: En torno al libro de Elvira de Azevedo Mea e Inácio Steinhardt, sobre la vida del capitán Arthur Carlos de Barros Basto (Abraham BenRosh)", Sefarad, 59-2 (1999), pp. 439-447.

STUDEMUND-HALÉVY, Michael, “Coming Out Jewish and Marrano No More”, Aschkenas, 25(2) (2015), pp. 281-291.

TAVARES, Maria de Fátima, Ha-Lapid (O Facho): análise do órgão oficial da Comunidade Israelita do Porto, Porto, [Edição do Autor], 2001.

“The growth of Judaism in Portugal”, in Jewish Daily Bulletin (19.7.1929), p. 3. 
VAN SON, Mordechai, Verleden en Heden der Marranen in Portugal, Amsterdam, Menno Hertzberger, 1930.

WILKE, Carsten L., "O Segredo dos Doutores: um círculo de Académicos Criptojudeus em Lisboa, 1593-1614”, in Belmonte. Inquisição. Criptojudaísmo. Marranismo, ed. António Bento, Covilhã, Universidade da Beira Interior, 2018, pp. 189-211.

WOLF, Lucien, Les Marranes ou Crypto-juifs du Portugal, Paris, Dangon, 1926.

\section{NOTES}

1. "Nós desejamos a este homem especial, que a sua obra floresça e aumente" (I. Elbogen, "Para a Inauguração..., p. 8; translation of "Synagogenweihe in Oporto...". This article had the support of CHAM (NOVA FCSH-UAC), through the strategic project sponsored by FCT (UID/HIS/ 04666/2019). Translations are mine unless otherwise noted. I also would like to thank the reviewers for their thoughtful comments and efforts towards improving the manuscript.

2. "Barros Basto is a legend about whom a biography is waiting to be written. But the life of a devout Jew with a cause that failed is hardly the stuff of best-sellers" (E. and R. Rosenthal, "The Portuguese Dreyfus ...", p. 44).

3. Bibliography on Barros Basto: I. Steinhardt, http://www.steinhardts.com/LIBRARY/ Biographies/ captain.html. For the most recent works, see D. Cohen, "Uma aproximação ...".

4. Os Cristãos Novos em Portugal...; The French version Les Crypto-Juifs portugais au XXe siècle (typewritten document dated Lisbon February 1925, Biblioteca Mário Sottomayor Cardia, Faculade de Ciências Socias e Humanas, Universidade Nova de Lisboa) includes an extract of a letter from Max Nordau in epigraph and is dedicated to his father-in-law Samuel Barbasch, deceased in Odessa (25.5.1922). It was recently published under the title La Découverte des marranes: les crypto-juifs au Portugal, Paris, Chandeigne, 2015, with a preface by Nathan Wachtel, an introduction and notes by Livia Parnes and a translation of the prayers and inquisitorial processes by Florence Lévi, Anne-Marie Quint and Bernard Tissier. See p. 358 the bibliography of the Italian and English translations of this work. In Portuguese, Schwarz uses the word NewChristian that officially refers to the converted Jews in Portugal since 1497. The word Crypto-Jew appears at the end of the eighteenth century, in particular in Johann von Starck's essay on « crypto-catholicism » (Über Krypto-Katholicismus ..., p. 414).

5. L. Wolf, "Les Marranes ... ", pp. 20-22 on Barros Basto.

6. "Les Marranes sont à la mode" (L. Dreyfus, "Uriel da Costa”, p. 300).

7. "Capitaine Barros Basto, nous aurons bientôt des Marranes en Russie" in L'Univers israélite (31.1.1930), p. 553 (henceforth abbreviated in UI).

8. See above note 2. Barros Basto, o Capitão mal-amado, RTP, 2003 (50'). J. Maltz, "Descendants of the 'Portuguese ...".

9. J. Brenner and S. Neumann, Les Derniers Marranes, 52.

10. E. Elger and L. Valente, A História dos Judeus em Portugal, 56.

11. S. Keslassi, History's Ultimate Nomads - Portugal, 30.

12. J. Gerber, The Portuguese Jewish Legacy, Congregation Shearith Israel, 2013, 59'. Asher Salah, who did research on the discovery of Crypto-Judaism in Portuguese documentary cinema, kindly confirmed to us this absence.

13. Elvira de Azevedo Mea and Inácio Steinhardt, Ben-Rosh. Biografia do Capitão Barros Basto o Apóstolo dos Marranos, 1997.

14. S. Pool, “The Marranos ...", pp. 247-250.

15. L. Jean-Javal, "Sous le charme ...”, p. iv; reprod. in H. Baudry-Kruger (ed.), La Renaissance ..., p. 59. 
16. See below List I, Barros Basto's visitors from 1927 to 1938.

17. "membro protector", HL 42 (August-September 1931), p. 6.

18. HL 59 (September 1933); later, he was elected honorary president of the Oporto Community.

19. HL 84 (March 1938), p. 2.

20. HL 74 (December 1936), p. 1. Like many other ones, Kadoorie's name is among those of the numerous donors of the Congregation of the Kahal Kadosh Mekor Haïm in April 1937 (HL 79 (April 1937), p. 3).

21. L. Wolf, Les Marranes..., p. 20.

22. HL 2 (May 1927). Barros Basto sent pictures to his friends abroad, as to Jean-Javal (HL 35 (December 1930), p. 6).

23. Artur C. de Barros Basto, Os Judeus no velho Porto ...", 1929, reviewed in HL 19 (April-May 1929), p. 8); see also A Sinagoga do Porto ..., 2014. On the works of Barros Basto, see D. Cohen, "Uma aproximação...".

24. See List 2 below. Couchoud, a French philosopher and writer, never went to Portugal.

25. HL 40 (June 1931) and 62 (February 1934), p. 1; a third French poem, "Jerusalem" (dated April 1931), was reproduced in HL 87 (September 1938), p. 1. See L. Jean-Javal, Nuages ..., 1933. JeanJaval's poetry, according to Jacques Eladan, is "completely forgotten nowadays" (J. Eladan, Poètes juifs ...", p. 101.

26. Jean-Javal briefly met them in Lisbon (J. Jean-Javal, Sous le charme..., p. 181-182). His son, Nuno, unveiled a picture of his father, the president of the Oporto community (HL 22 (AugustSeptember 1929), p. 2-3); on Nuno's brit milah: HL 18 (March-April 1929), pp. 2-3; and bar-mitsva: HL 69 (December 1934-February 1935), pp. 4-5.

27. L. Jean-Javal, "Le Capitaine ...". A summary of the conference read on Sunday, March, 2, was released a few days later (“Au 'Chema' Mme Lily Jean-Javal et les Maranes”, UI, 7.3.1930, p. 717) and long extracts reproduced in HL 31 (June-July 1930), pp. 3-5.

28. "valente militar" (P. Goodman, "Os Maranos Portugueses. Inauguração da Sinagoga Kadoorie", in HL 83 (January-February 1938), p. 3; this article was translated from "Les Marranes portugais. Inauguration de la synagogue Kaddorie", in Le judaïsme sephardi, 58 (31.1.1938), pp. 3-5). On Barros Basto during the WWI, see Barros Basto: o Capitão nas trincheiras, 2015.

29. HL 100 (July-August 1940), p. 1. France's great rabbi Israel Lévy, who did not personally meet Barros Basto, joins his military courage and Jewish missionary spirit, calling him a "courageous brother" ("valente irmão" in HL 83 (January-February 1938), p. 7.

30. "J'ai vu sa photographie : un militaire avec des moustaches. [...] il m'attend, debout, dans son uniforme bleu d'officier d'infanterie [...] il a coupé sa moustache." (L.Jean-Javal, Sous le charme..., p. 11, 16; L. Jean-Saval, La Renaissance..., p. 64); Jean-Javal's book contains an updated picture of Barros Basto (between pp. 96-97).

31. HL 24 (October 1929), p. 4.

32. R. Lœwel, À la recherche ..., p. 134. On the date of their meeting, see the following note.

33. R. Lewel [=Lœwel], "Les Maranes ...", p. 106; A la recherche..., p. 151. When did Lœwel, a famous French lawyer and writer, visit Barros Basto? In À la recherche..., written "before the Spanish Civil War" (p. 8), Lœwel relates his visit to the monastery of São Vicente de Fora where D. Manuel II's wooden coffin was exhibited on a table since the fallen King's body had been repatriated by the British Navy in Lisbon on August 2, 1932 (R. Loewel, À la recherche..., p. 107). The Archives israélites refer to an undated article by Lœwel in the journal L'Euvre (not accessed) on his Iberian trip which thus happened between August 1932 and the Spring 1933.

34. E. Mea and I. Steinhardt, Ben-Rosh..., pp. 182-219.

35. E. Mea and I. Steinhardt, Ben-Rosh..., pp. 53-54.

36. L. Wolf, Les Marranes..., p. 20.

37. E. Mea and I. Steinhardt, Ben-Rosh..., pp. 55-56. 
38. C. Roth, "O Apóstolo dos Maranos ...", pp. 1-5 and 26 (December 1929), p. 3-5. The French version was published some weeks later: "L'Apôtre des Maranes", in UI, 10 (17, 24.1.1930), p. 453-455, 489-491, 521-522. The original was written in English in London and dated July 1929. Some historians, considering the catholic meaning of the word apostle, found its use paradoxical. Apostle, hachaliakh in Hebrew, means emissary, messenger. An earlier token of "apostle" can be found in a report by the correspondent of the Jewish Telegraphic Agency in Lisbon: "Captain Arthur Carlos de Barros Basto, the founder and president of the Jewish Community of Oporto, himself an ex-Marrano, is the apostle and the inspiring leader of the movement of the Portuguese Marranos to Judaism." ("The growth of Judaism in Portugal", in Jewish Daily Bulletin (19.7.1929), p. 3). "Mensageiro do resgate" is also used in Ha-Lapid to refer to Samuel Schwarz in accordance with his mission in the district of Castelo Branco (HL 19 (April-May 1929), p. 3).

39. Beyond French and Portuguese: German (by Alfonso Cassuto) and Italian (by José Pardo Roques) (HL 26 (December 1929), p. 5. The article also mentions a Dutch translation without further indication. It is likely to be Van Son'book Verleden en heden der Marranen in Portugal [Past and Present of the Marranos in Portugal] (Amsterdam, 1930, 16 p., 5 figures).

40. Goodman, HL 8 (January 1928), p. 2.

41. Goodman, HL 83 (January-February 1938), p. 5.

42. HL 1 (April 1927), p. 1.

43. HL 45 (December 1931-January 1932), p. 5.

44. HL 26 (Decembre 1929), p. 4; UI (31.1.1930), p. 522; La Renaissance..., p. 53.

45. L. Jean-Javal, Sous le charme..., p. 67 ; L. Jea-Javal, La Renaissance..., p. 97.

46. L. Jean-Javal, Sous le charme..., p. 27; L. Jean-Javal, La Renaissance..., p. 73.

47. L. Jean-Javal, Sous le charme..., pp. 74-77; L. Jean-Javal, La Renaissance..., pp. 103-105.

48. M. Ehrenpreis, Le Pays ..., p. 89.

49. HL 83 (January-February 1938), p. 3.

50. In a report to the Portuguese Marranos Committee, Goodman explained that the new-born jewish community of Portugal needs an "official religious guide" (HL 8 (January 1928), p. 3). Would Barros Basto ever feel the desire to become a rabbi? His historical research led him to initiate a book on the "supreme chiefs of the Portuguese Jews" since 1497 (HL 62 (February 1934), p. 4; see Cohen, “Uma aproximação...”, p. 88.

51. HL 74 (December 1935-January 1936), p. 8.

52. "De cette Communauté, il est à la fois le président, l'officiant, le trésorier, le secrétaire et la bonne fée." (L. Wolf, Les Marranes..., p. 20.)

53. M. Ehrenpreis, Le Pays..., p. 95.

54. "amador de realidades" (Elbogen, "Para a Inauguração", p. 6; see his tours with Roth in "the old ghetto of Olival" (HL 29 (March-April 1930), p. 5), Jacob Nachbin (HL 16 (December 1928January 1929), p. 8) or Elbogen (HL 82 (Nov.-Dec. 1937), p. 6), or longer walks with Jean-Javal through the historical centre of the city but also in Lisbon (L. Jean-Javal, Sous le charme..., p. 266-267; L. Jean-Javal, La Renaissance..., p. 128-9).

55. M. Ehrenpreis, Le Pays..., p. 89.

56. HL 25 (Nov. 1929), p. 1; La Renaissance..., p. 39, 40.

57. "talvez o episódio mais romanesco de toda a historia contemporanea", HL 25 (Nov. 1929), p. 3; La Renaissance..., p. 45.

58. "personalidade, talvez a mais magnética de quantas eu me havia aproximado", HL 25 (Nov. 1929), p. 5; La Renaissance..., p. 48.

59. “Son sourire était l'expression de confiance" (Jean-Javal, "Une Synagogue s'élève à Porto", in HL 35 (December 1930), p. 6 (article first published in UI); La Renaissance..., p. 134).

60. “o seu coração juvenil” (HL 82 (Nov.-Dec. 1937), p. 7).

61. L. Jean-Javal, Sous le charme..., 60; see also p. 105; L. Jean-Javal, La Renaissance..., pp. 92 and 111. 
62. HL 25 (Nov. 1929), p. 5; L. Jean-Javal, La Renaissance..., p. 50. Many jewish jokes ("Historietas judaicas" or "talmudicas") can be found in HaLapid but their origin is not clear (either from Barros Basto or Norberto Moreno, who signs some of them (HL 77 (October-November 1936), p. 7). 63. "Mensageiro do Resgate (como graciosamente se qualifica ao proprio)" (HL 25 (Nov. 1929), p. 3-4); "l'Émissaire des maranes (comme lui-même se designe avec une certaine fantaisie)" (UI (31.1.1930), p. 489). Only in this sense, and taking into account some self-irony, we can say with M. Studemund-Halévy that Barros Basto was "the self-appointed "Apostle of the Marrano"' (“Coming Out ...", p. 285).

64. J. Klatzmann, L'Humour ..., p. 115.

65. L. Jean-Javal, Sous le charme..., pp. 23-24; L. Jean-Javal, La Renaissance..., p. 70.

66. L. Jean-Javal, “Une Synagogue...”, p. 6; L. Jean-Javal, La Renaissance..., p. 133.

67. HL 85 (April-May 1938), p. 3.

68. HL 83 (January-February 1938), p. 3.

69. P. Goodman, "L'inauguration ... ", p. 18.

70. HL 35 (December 1930), p. 7; L. Jean-Javal La Renaissance..., p. 134.

71. Conference in New York on the Portuguese Marranos (HL 29 (March-April 1930), p. 8).

72. E. Mea and I. Steinhardt, Ben-Rosh..., p. 53.

73. “nós chamamos a ele cordealmente 'Chasak Weemaz"' (I. Elbogen, “Para a Inauguração...”, p. 6).

74. See his report of the trial in Lisbon (E. Mea and I. Steinhardt, Ben-Rosh..., pp. 216-217).

75. I. Elbogen, "Para a Inauguração...", p. 8. On the antisemitic intimidation suffered by Barros Basto, see above, note 33, his remarks to Robert Lœwel.

76. I. Elbogen, "Para a Inauguração...", p. 8.

77. "Lucien Wolf", HL 32 (July-August 1930), p. 7.

78. "uma das mais marcantes personalidades hebraica[s] do nosso tempo" (HL 25 (November 1929), p. 1).

79. C. Roth, A History ...

80. Salomon quoting Roth's foreword in the third edition (1959) (C. Roth A History..., Introduction, p. viii).

81. "El ascenso del nazismo y el Holocausto, la creación del Estado de Israel así como el temor a manifestar públicamente cualquier religiosidad diferente de la católica en el Portugal salazarista, trajeron consigo un espeso velo de silencio y de olvido voluntario, como si años antes nada hubiese ocurrido" (c. Stuczynski, "Marranismo ...", p. 441.

82. https://www.yadvashem.org/righteous/stories/mendes.html (accessed 20.10.2019).

83. "Dieses Stillschweigen hatte etwas Rätselhaftes" (Y. Bato, "Was geschah ...", p. 17.

84. Y. Bato, "Was geschah...", respectively pp. 16, 17. The issue of the end of the Portuguese Marrano revival needs further investigations.

85. See J. Martins, A República ..., pp. 151-153.

86. "Há uns trinta a quarenta anos, ainda existiam em certas províncias do Norte fortes núcleos de cristãos-novos, que seguiam certas tradições religiosas judaicas. Essas tradições criptojudaicas estão agora desaparecendo a olhos vistos. O que a Inquisição não conseguiu em três séculos de perseguições e de fogueiras, conseguiram-no três décadas de tolerância e de liberdade..." (S. Schwarz, "História da moderna ..., p. 160).

87. E. Mea and I. Steinhardt, Ben-Rosh..., p. 237.

88. L. Parnes, “Samuel Schwarz, chercheur infatigable ... ”. See also L. Parnes's Présences juives ...

89. On this debatable topic in the New Christian/Marrano early modern culture, see C. Wilke, "O Segredo dos Doutores ... ", pp. 189-211.

90. S. Schwarz, La Découverte..., p. 44. Maria de Fátima Tavares aludes to the "indifference of the powerful families of Lisbon" towards Barros Basto's Work of Redemption, in Ha-Lapid ..., p. 49. 
91. The article by António Ribeiro dos Santos was to be continued (HL 156 (September 1958), p. 8). On the history of the jornal, beyond Tavares, see L. Parnes's Ha-Lapid (O Facho)...

92. M. Studemund-Halévy, "Coming Out Jewish...” p. 288.

93. From HL 1-89, Sections "Obra do Resgate", "Vida communal" (except Lisbon). To be added one "fadar", in 1931.

94. Three years before the inauguration, Paul Goodman had proposed that the Oporto synagogue be the property of the SPC (HL 69 (January-February 1935), p. 5.

95. HL 84 (March 1938), p. 4.

96. Each entry indicates the name of the visitor, the town or country of origin, the period of their stay(s) in Oporto (data mainly drawn from Ha-Lapid).

97. See above, note 33 .

\section{ABSTRACTS}

Arthur de Barros Basto (Amarante, 1887-1961), known as the "Apostle of the Marranos" and the "Portuguese Dreyfus", returned to Judaism in 1920. After centuries of repression, it could flourish in the young Republic identically to every religion. But flourishing meant resuscitating. Whereas in the 1930's Sionism was spreading in the European political and intellectual circles, Barros Basto committed into resuscitating Israel in his own country. He became internationally famous, gaining means and strength to achieve his mission, turning a public figure that this paper aims at shaping through contemporary testimonies and travel narratives.

Arthur Barros Basto (Amarante, 1887-1961), conhecido como o "Apóstolo dos Marranos" e o "Dreyfus Português", voltou à fé judaica em 1920. Após séculos de repressão, o judaismo podia florescer na jovem república como qualquer outra religião. Mas florescer significava ressuscitar. Enquanto, nos anos 1930, o ideal sionista expandia-se nos meios políticos e inteletuais europeus, Barros Basto obrou em prol de uma resurreição de Israel dentro do seu país. Ganhou fama a nível internacional, recebendo meios e força para cumprir a sua missão, tornando-se assim uma figura pública que este artigo restitui através dos testemunhos e narrativas de viagem da época.

\section{INDEX}

Keywords: Arthur Barros Basto, Judaism, Portugal, Inter-War period, travel narrative Palavras-chave: Arthur Barros Basto, Judaismo, Portugal, Período Entre-Guerras, narrativa de viagem

\section{AUTHOR}

HERVÉ BAUDRY

Senior Researcher

CHAM, FCSH-UL 